DOI https://doi.org/10.18551/rjoas.2018-09.60

\title{
ANALYSIS OF THE EFFICIENCY OF THE USE OF PRODUCTION FACTORS OF CUCUMIS LATIVUS FARMING IN ARISAN GADING VILLAGE, SOUTH INDRALAYA SUBDISTRICT OF OGAN ILIR DISTRICT, INDONESIA
}

\author{
Mulyana Eka \\ Faculty of Agricultrual, University of Sriwijaya, Sumatra, Indonesia \\ E-mail: eka.agri@gmail.com
}

\begin{abstract}
This study aimed to analyze the level of efficiency of the use of factors of production in cucumis sativus farming in Arisan Gading Village, South Indralaya Subdistrict of Ogan Ilir District. It used a survey method. The sampling technique used a purposive sampling method. Based on the results of calculations, the use of land, labor, seeds, NPK (Nitrogen, Phosphorus, and Potassium) fertilizer, and allocative herbicides were inefficient so that their use needs to be reduced to achieve optimal production, while the use of insecticide production factor was not efficient so its use needs to be increased.
\end{abstract}

\section{KEY WORDS}

Cucumis Sativus, efficiency level, production, factors.

Indonesia is indeed a paradise for all of us who are fond of farming activities because almost all trees or plants can live in this agrarian land. Having supportive natural conditions, we can in fact take advantage of opportunities to boost business in the agricultural sector. Cultivation of cucumis lativus is one of the opportunities that we can try to take advantage of because this fruit is very popular in the life of Indonesian people. All of the above factors are ineffective enough if there is no policy from the government supporting the agricultural development. Cucumis lativus is rich in provitamin A, functioning as a natural antioxidant to prevent damage to body cells. In addition, it has a high vitamin $\mathrm{C}$ content. It is rich in essential minerals such as calcium, phosphorus, and iron. It also has health benefits such as controlling sugar levels in the body, reducing the risk of cancer, helping the regeneration process of body cells, and helping to improve digestion.

South Sumatra is one of the provinces where farmers cultivate cucumis lativus because during the month of Ramadan the demand for cucumis lativus increases. Moslems often have it as an iftar menu. Therefore, the farmers plant it. This fruit is frequently processed into a refreshing drink. For health benefits, cucumis lativus can be used to control sugar levels in the body, reduce the risk of cancer, help the regeneration process of body cells, and help to improve digestion. South Indralaya Subdistrict is one of the subdistricts of Ogan Ilir District, South Sumatra Province where farmers regularly plant cucumis lativus when facing the upcoming Ramadan month. According to the Central Statistics Agency (2017), the average production of cucumis lativus in South Indralaya Subdistrict in 2016 was 8 tons of an average land area of 9 hectares.

The production of cucumis lativus is strongly influenced by the production factor since it will affect the income of the farmers to be high or low earnings. In addition, the level of efficiency of production factor needs to be taken into account so that farmers is aware whether their use of production factor is already efficient or not. In this way, they can use production factors in accordance with the needs and efficiency of the cucumis lativus plant.

Based on the background, the researcher was interested in conducting a study on the Analysis of Efficiency Level of the Use of Production Factors of Cucumis Lativus Farming in Arisan Gading Village, South Indralaya Subdistrict of Ogan Ilir District

\section{METHODS OF RESEARCH}

Research Location and Time. This research was conducted in Arisan Gading Village, South Indralaya Subdistrict of Ogan Ilir District. The location was determined purposively by 
considering that the farmers of the Village had the cucumis lativus farming. The Village area is potential in agriculture, and most of the people there earn a living by growing cucumis lativus plants. The study started in March 2018 until completion.

Research Method. A research method is needed in order to measure the success of a study. This study used a survey method. According to Putra (2010), a survey method is a way of collecting data through inquiries from certain parties. The samples were taken from the farmers of cucumis lativus of Arisan Gading Village, South Indralaya Subdistrict, Ogan Ilir District. The survey was conducted directly using questionnaires as a means of collecting basic data and conducting interviews with resource persons as the sample representing the population of cucumis lativus farmers of Arisan Gading Village. This method was carried out to obtain thorough, factual data and facts from the the study object area.

Sampling Technique. The study used a purposive sampling technique. Putra (2010) states that purposive sampling is a technique of selecting sample with certain (objective) considerations. Sampling in the field was conducted by interviewing 30 samples. They were farmers of cucumis lativus of Arisan Gading Village, Indralaya Selatan Subdistrict of Ogan Ilir District.

Method of Data Collection. The collected data in this study were derived from primary and secondary data. The primary data were collected using an interview guideline or prepared questionnaire. The list of questions or questionnaire used in this study contained questions related to cucumis lativus farming and the factors of production used. This study took some photos for documentation. While secondary data were gathered from library sources, internet, village monographs of sample locations, and related agencies.

Method of Data Analysis. This study aimed to measure the level of efficiency of the use of production factors by using the following formula:

$$
\frac{d y}{d x}=\beta \mathrm{i}
$$

The marginal mathematical product equation derived from the use of the i production input $\left(\mathrm{PM}_{\mathrm{xi}}\right)$ is:

$$
\mathrm{PM}_{\mathrm{xi}}=\frac{d y}{d x}=\frac{d(P T)}{d x}
$$

As for the tabulated data (discrete), the $\mathrm{PM}_{\mathrm{xi}}$ is obtained from the change of output divided by change of input:

$$
\mathrm{PM}_{\mathrm{xi}}=\frac{\Delta Y}{\Delta X}
$$

To get the Marginal Product Value of the use of production inputs (NPM $M_{x i}$ ), the two segments of the last equation above are multiplied by the product price (Py) to obtain:

$$
N P M_{x i}=P M_{x i} \cdot P y=\beta i \frac{Y}{X_{i}} \cdot P y=P_{x i}
$$

Furthermore, the determination of efficiency criteria can be done by using the ratio of the Marginal Product Value to the price of the production factor $\left(N_{P M} M_{x i} / P_{x i}\right)$ with the following conditions:

$$
\begin{aligned}
& k=\frac{N P M_{x i}}{P_{x i}}=1 \\
& k=\frac{N P M_{x i}}{P_{x i}}>1 \\
& k=\frac{N P M_{x i}}{P_{x i}}<1
\end{aligned}
$$

The use of efficient $X_{i}$ production factors or maximum profit achieved.

The use of $X_{i}$ production factors is inefficient or less than what is needed so the amount needs to be added.

The use of $X_{i}$ production factors is inefficient or exceeds the needs so that the amount needs to be reduced. 
Where:

NPM $_{\mathrm{xi}}$ : Marginal product value derived from the factor of production to i (Rupiah);

Py: Production unit price (Rupiah);

$\mathrm{P}_{\mathrm{xi}}$ : Production factor unit price to i (Rupiah);

$\beta_{\mathrm{i}}$ : Coeffcient;

$\mathrm{X}_{\mathrm{i}}$ : Production average to $\mathrm{i}$.

\section{RESULTS AND DISCUSSION}

Efficient Use of Production Factors. Efficiency is defined as an effort to use the smallest input to get the maximum output (result). Production is optimum if production factors are used as efficiently as possible. In this study, the analysis of allocative efficiency (price) was carried out. The allocative efficiency of the use of production factors is achieved if the Marginal Product Value (NPMx) is the same as the unit price of the production factor used. This situation shows that the use of these production factors is optimum at a certain level of output without having to be added or reduced

The results of this study showed that the average use of production factors per planting season of cucumis lativus farming of Arisan Gading Village in 2018. The production factors were the area of land, labor, seeds, NPK fertilizer, herbicides, and insecticides. The average land area used for cucumis lativus farming was 0.70 hectares. The average use of production factors per planting season per year for labor was $48.58 \mathrm{HOK}, 0.63$ kilograms of seeds, 169.50 kilograms of NPK fertilizer, 0.74 liters of herbicides and 1.9 kilograms of insecticides. Meanwhile, the average production of cucumis lativus was 4,473 kilograms per arable area per planting season with the average selling price of Rp. 3,000.00 per kilogram. The cost or price of an input or factor of production is the expense that must be incurred by the farmer to get the production factor. All cucumber farmers of Arisan Gading village used their own land, so to find out the average price of land per plot of land, it was Rp.30,000,000.00 per hectare, so that the average land rent was Rp. 21,050,000.00 per arable area per planting season. The average cost incurred for labor wages was Rp. 24,338.34 per HOK. The price of cucumber seeds was calculated based on the prevailing seed prices in Arisan Gading Village, which was Rp.40,666.67 per kilogram. The price of NPK fertilizer was calculated based on the average cost incurred by farmers, which was Rp.6,937.00 per kilogram. The average price for buying herbicides was Rp.67,500.00 per liter. The average price of insecticides was Rp.50,000 per kilogram. The allocative efficiency of the use of production factors of the cucumis lativus farming in 2018 was obtained from the calculation of the level of each efficiency. The calculation results are given in Table 8.14.

Table 1 - The level of efficiency in the use of production factors of cucumis lativus farming of Arisan Gading Village in 2018

\begin{tabular}{lllllll}
\hline Production Factor & PR & PM & NPM & Hxi & K & Criteria \\
\hline Land Area $\left(X_{1}\right)$ & $6,375.30$ & $5,871.65$ & $17,614,945.37$ & $21,050,000.00$ & 0.84 & Inefficient \\
LAbor $\left(X_{2}\right)$ & 92.08 & -21.09 & $-63,261.43$ & $24,338.34$ & -2.60 & Inefficient \\
Seeds $\left(X_{3}\right)$ & $7,081,79$ & -311.60 & $-934,796.83$ & $40,666.67$ & -2.99 & Inefficient \\
NPK Fertilizer $\left(X_{4}\right)$ & 26.39 & 1.27 & $3,800.35$ & $6,937.07$ & 0.55 & Inefficient \\
\hline Herbicides $\left(X_{5}\right)$ & $6,031.46$ & -132.69 & $-398,076.40$ & $67,500.00$ & -5.90 & Inefficient \\
Insecticides $\left(X_{6}\right)$ & $2,356.45$ & 266.28 & $798,837.58$ & $50,000.00$ & 15.98 & Not Yet Efficient \\
\hline
\end{tabular}

Source: Processed primary data, 2018.

Land Use. The ratio between the Marginal Product Value $\left(N P M_{x 1}\right)$ to $H_{x 1}$ was less than one $\left(\mathrm{NPM}_{\mathrm{x} 1} / \mathrm{H}_{\mathrm{x} 1}\right.$ or $\left.\mathrm{k}=0.84\right)$, which means that the land production factor was inefficient at a $95 \%$ of confidence interval, so the used land area needs to be reduced to get optimal production. Therefore, the hypothesis of this study stating that the factors of land production was inefficient was rejected. The marginal product of land production factor was 5,871.65. This shows that each addition of 1 hectare of land will increase the cucumis lativus production by $5,871.65$ kilograms. Meanwhile, the result of the NPM calculation show that the obtained land NPM was Rp.17,614,945.00 per arable area per planting season. This 
figure is the addition of the cucumis lativus production value derived from the addition of one hectare of land.

Use of Labor. The ratio between the Marginal Product Value of $\left(\mathrm{NPM}_{\mathrm{x} 2}\right)$ to the average labor wage $\left(\mathrm{H}_{\mathrm{x} 2}\right)$ was less than one $\left(\mathrm{NPM}_{\mathrm{x} 6} / \mathrm{H}_{\mathrm{x} 6}\right.$ or $\left.\mathrm{k}=-2.60\right)$. This means that the use of labor was inefficient so that the workforce needs to be reduced. The hypothesis of this study stating that the factor of labor production was not yet efficient was rejected.

The marginal product of the factor of labor production was -21.09 kilograms. This shows that every addition of $1 \mathrm{HOK}$, labor supply would reduce the production of cucumis lativus by 21.09 kilograms. Meanwhile, the result of the NPM calculation showed that the obtained NPM of the workforce was Rp. 63,261.43. This figure is a reduction of the production value of cucumis lativus for each additional $1 \mathrm{HOK}$.

Use of seeds. The ratio between the Marginal Product Value $\left(\mathrm{NPM}_{\mathrm{x} 3}\right)$ to $\mathrm{H}_{\mathrm{x} 3}$ was less than one $\left(\mathrm{NPM}_{\mathrm{x} 3} / \mathrm{H}_{\mathrm{x} 3}\right.$ or $\left.\mathrm{k}=-22.99\right)$, which means that seed production factor was inefficient at $95 \%$ confidence intervals so that the seed dose needs to be reduced to obtain optimal production. Therefore, the hypothesis of this study stating that the factor of seed production was not yet efficient was rejected. The marginal product of the seed production factor was 311.60 kilograms. This shows that every addition of 1 kilogram of seeds would reduce the total cucumis lativus production by 311.60 kilograms. Meanwhile, the NPM calculation result showed that the obtained NPM seeds was Rp. 934,796.83 per kilogram. This figure is a decrease in the production value of cucumis lativus obtained from the addition of 1 kilogram of seeds.

Use of NPK Fertilizer. The ratio between the Marginal Product Value $\left(\mathrm{NPMx}_{4}\right)$ to $\mathrm{Hx}_{4}$ was more than one $\left(\mathrm{NPMx}_{4} / \mathrm{Hx}_{4}\right.$ or $\left.\mathrm{k}=0.55\right)$. Thus the production factor of NPK fertilizer was inefficient at $95 \%$ confidence intervals so that the dose of fertilizer use needs to be added to achieve optimal production. Therefore, the hypothesis of this study stating that the factor of production of NPK fertilizer was inefficient was rejected. The marginal product of the NPK fertilizer production factor was 1.27 kilograms. This shows that every addition of 1 kilogram of NPK fertilizer would increase the production of cucumis lativus by 1.27 kilograms. Meanwhile, the NPM calculation result showed that the NPM of NPK fertilizer obtained was Rp.3,800.35 per kilogram. This figure is the addition of the cucumis lativus production value derived from the addition of 1 kilogram of NPK fertilizer.

Use of Herbicides. The ratio between the Marginal Product Value $\left(\mathrm{NPMx}_{5}\right)$ to the herbicide production factor price $\left(\mathrm{Hx}_{5}\right)$ was less than one $\left(\mathrm{NPMx}_{5} / \mathrm{Hx}_{5}\right.$ or $\left.\mathrm{k}=-5.90\right)$. This shows that the factor of herbicide production was inefficient at $95 \%$ confidence intervals so that the use of herbicides needs to be increased. Therefore the hypothesis of this study stating that the use of herbicide was inefficiently was rejected. The marginal product of the herbicide was -132.69 kilograms which means that every addition of 1 liter of herbicide would decrease the amount of production by 132.69 kilograms. Meanwhile, the marginal product value of the herbicide was $-398,076.40$. This value is a decrease in the production value of Rp. 398,076.40 derived from each addition of one liter of herbicide.

Use of Insecticides. The ratio between the Marginal Product Value of $\left(\mathrm{NPMx}_{6}\right)$ to the average insecticide price $\left(\mathrm{Hx}_{6}\right)$ was greater than one $\left(\mathrm{NPMx}_{6} / \mathrm{Hx}_{6}\right.$ or $\left.\mathrm{k}=15,977\right)$. This means that the use of insecticides was inefficient so that the amount of use needs to be increased. Therefore, the hypothesis of this study stating that insecticide production factors was inefficient was accepted. The marginal product of the insecticide production factor was 266.28 kilograms. This shows that each addition of one kilogram of insecticides would increase the production of cucumis lativus by 266.28 kilograms. Meanwhile, the result of the NPM calculation showed that the obtained insecticide NPM was Rp. 798,837.58. This figure is the addition of cucumis lativus production value for each addition of one kilogram of insecticides.

\section{CONCLUSION}

The average use of production factors per planting season per year for labor was 48.58 HOK, 0.63 kilograms of seeds, 169.50 kilograms of NPK fertilizer, 0.74 liters of herbicides 
and 1.9 kilograms of insecticides. Meanwhile, the average production of cucumis lativus was 4,473 kilograms per arable area per planting season with the average selling price of Rp. $3,000.00$ per kilogram. The cost or price of an input or factor of production is the expense that must be incurred by the farmer to get the production factor. while the use of insecticide production factor was not efficient so its use needs to be increased.

\section{REFFERENCES}

1. Badan Pusat Statistik Kecamatan Inderalaya Selatan.2017. Kecamatan Inderalaya Selatan dalam Angka 2017 [online].http;//sumsel.bps.go.id/beckend/pdf_publikasi /Provinsi-Sumatera-Selatan-dalam-Angka-2017.pdf [diakses pada tanggal, 02 agustus 2018].

2. Chayanov, A.V. 1966. The Theory of Peasant Economy (Edited by Daniel Thorner, Basile Kerblay and R.E.F. Smith). Illinois: Homewood

3. Drucker, Peter Ferdinand. 1909. Inovation and entrepreneurship. Sidney Feinberg. New York. ISBN 0-06-091360-6.

4. Duth, Kenneth D. 1979. Principles of management in agribusiness. Reston Publishing Company, Inc. Aprentice-Hall Company. Reston, Virginia. ISBN 0-8359-5595-8.

5. Husin, L dan Lifianthi. 2008. Ekonomi Produksi Pertanian. Fakultas Pertanian Universitas Sriwijaya. Indralaya

6. Putra.I.D.P and W.S. Untari. 2010. Analisis Usahatani Blewa di Desa Demang Kecamatan Besuki [online]. https://unars.ac.id/jurnal/berita-163-analisis-usahataniblewah-di-desa demung -kecamatan-nesuki-study-kasus-di-desa-demung-kec-besuki-kahtml. [diakses 17 mei 2018].

7. Tiwari, Ak. 2013. Economic growth, energy consumption, financial development, international trade and CO2 emissions in Indonesia. Renewable and Sustainable Energy Reviews Volume 25, September 2013, Pages 109-121

8. Wildayana, E. 2012. The Analyses Structure and Household Income Distribution of Palm Oil (Elaeisguineensis Jacq) Farmers NES-TRANS in South Sumatra, Indonesia. The UMT 11th International Annual Symposium on Sustainability Science and Management, p. 1480-1487, e-ISBN 978-967-5366-93-2. 